\title{
Economic valuation of the Emas Waterfall, Mogi-Guaçu River, SP, Brazil
}

\author{
JANICE PEIXER ${ }^{1, *}$, HENRIQUE C. GIACOMINI ${ }^{2}$ and MIGUEL PETRERE $\mathbf{J r}^{2,3,4}$ \\ ${ }^{1}$ Centro de Pesquisa e Conservação de Peixes Continentais (CEPTA), \\ Instituto Chico Mendes de Conservação da Biodiversidade, \\ Rodovia SP, 201, Caixa Postal 64, 13630-970 Pirassununga, SP, Brasil \\ ${ }^{2}$ Departamento de Ecologia, Universidade Estadual Paulista "Júlio de Mesquita Filho", \\ Campus de Rio Claro, Avenida 24-A, 1515, 13506-900 Rio Claro, SP, Brasil \\ ${ }^{3}$ PG em Direito Ambiental, Universidade do Estado do Amazonas (UEA), \\ Rua Leonardo Malcher, 1728, $5^{\circ}$ andar, (Praça XIV), 69020-070 Manaus, AM, Brasil \\ ${ }^{4} \mathrm{PG}$ em Biologia Urbana, Universidade Nilton Lins, \\ Avenida Prof. Nilton Lins, 3259, Parque Laranjeiras, 69058-040 Manaus, AM, Brasil
}

Manuscript received on July 23, 2010; accepted for publication on March 30, 2011

\begin{abstract}
The Emas waterfall in Mogi-Guaçu River is regionally recognized as an important fishing spot and touristic place. The first reports of the professional and sport fishing there date back from the 30's, which is the same period when the tourism took place. The present paper provides an environmental valuation of this place and an assessment of the differences among the major groups of people using the area. During 2006 we interviewed 33 professional fishers, 107 sport fishers, 45 tourists and 103 excursionists in order to estimate the Willingness to Pay (WTP) for each category and to analyze the influence of socioeconomic factors by means of logistic regressions and ANCOVAs. The WTP of professional fisher was significantly influenced by age and education, and the WTP for the sport fishers was influenced by the family income. The variables that influenced the tourists' and excursionists' WTP were sex and education. The total annual aggregated value to maintain the waterfall in the current conditions was estimated in US\$ 11.432.128, and US\$ 55.424.283 to restore it.
\end{abstract}

Key words: contingent valuation method, professional fishing, sport fishing, tourism, Willingness-to-pay.

\section{INTRODUCTION}

The economical value of a natural resource is in its importance for the social well-being. Its valuation is a trade-off analysis, in other words, measuring what the human beings are willing to give up in order to improve the amount or the quality of the natural resources (Ortiz 2003). Valuating any natural resource is attributing it a monetary value in relation to other services and available goods in the economy (Motta 1998). For Costanza

\footnotetext{
Correspondence to: Janice Peixer

*Present Address: Instituto Federal de Educação, Ciência e Tecnologia de São Paulo, Campus Caraguatatuba, Av. Rio Grande do Norte, 450, Indaiá, 11665-310 Caraguatatuba, SP, Brasil

E-mail: janicepx@hotmail.com
}

(1991), the unvalued environmental goods and services are considered available without any price.

The biodiversity, the environmental services and the natural resources are over risk to be exhausted, as they provide real functions and positive economical benefits, but they are treated as having a null price (Mattos and Mattos 2004). There is urgent need to valuate the natural resources correctly and to integrate such information to the economical politics in order to correct the negative tendencies of the free market. It could allow integrating also the environmental issues to economical development strategies (Ortiz 2003). The technique of environmental valuation is not concerned simply with providing the environment or the resource 
a given price, but rather with the valuation of people's preferences in relation to changes in the resource quality or availability (Ortiz 2003), which demonstrates the economical benefits offered by them and the correspondent losses if they are depleted (Mattos and Mattos 2004).

Navrud (2001) presents three other reasons to valuate natural resources: (i) it allows to determine the optimal quality and availability of environmental goods; (ii) if valuation is not carried out scientifically, it will be done (correctly or not) by political decisions; and (iii) the valuation is also necessary to decide which laws and projects are socially more desirable. According to Rivas and Kahn (2006), the degradation of several rivers that used to be sources of low cost leisure for a lot of people, has increased the value attributed to them by the society. The same applies to fisheries resources.

The objective of the present paper is to provide an economic valuation of the Emas waterfall by estimating the Willingness to Pay (WTP) of several publics that use it for income and tourism. We also tested the influence of socioeconomic variables on WTP to maintain the environment in its current conditions, or to recover it.

\section{MATERIALS AND METHODS}

\section{STUDY AREA}

Mogi-Guaçu River headstreams are located in the state of Minas Gerais, in the county of Bom Repouso in the Mantiqueira mountain chain, in an altitude of $1.650 \mathrm{~m}$. In the states of Minas Gerais and São Paulo, its basin total drainage area is $17.460 \mathrm{~km}^{2}$, (Brigante et al. 2002) (Fig. 1). It is $473 \mathrm{~km}$ long till its confluence with Pardo River in the Paraná basin. Just 5.9 per cent of its natural vegetation remains.

In the Mogi-Guaçu River basin, agricultural and industrial activities are intensive. The former is more remarkable in the state of Minas Gerais, and the latter in the state of São Paulo. As a consequence, the original riparian vegetation virtually disappeared. Moreover, most of the municipal districts discard its domestic and industrial effluents into the river, with little or no treatment. The declining of many fish species, especially the piracanjuba Brycon orbygnianus, is a consequence of the negligence with the river biotic integrity (Godoy 1974).
The Emas waterfall (which in fact is a rapid) is located in the middle Mogi-Guaçu River, and it gives the same name to the district in the municipality of Pirassununga, located at $7 \mathrm{~km}$ from downtown. There is a small dam built in the 20's for electric power generation, now out of operation.

\section{SAMPLING}

In order to estimate the value attributed the Emas waterfall we interviewed, from February to December 2006, every professional fishers who act in this area (33), 107 sporting fishers, 103 people which used the local restaurants or which stayed there for up to a day (excursionists) and 45 who stayed in local hotels during some days (tourists). We used the definition of Beni (1998), for whom a tourist is a temporary visitor who spends at least twenty-four hours in the place due to recreation, vacation, health and business, among other reasons; and an excursionist is a temporary visitor who spends less than twenty-four hours at the visited place. Although some tourists may be found fishing, it is not their main objective there, which distinguishes them from the sport fishers.

As the sport fishers were sequentially positioned along the river, we sampled them in a systematic manner. We interviewed $20 \%$ of them in the sampling area at each day. They were numbered following the ordering along the river or the boats' positions. Among the first six fishers, the first interviewee was randomly chosen by means of a die. After him, we proceeded by choosing every fifth fishers in the sequence until completing the sample size. Only 18 years old or older fishers were selected for the interview. The tourists and excursionists available to the interview were found in a more unpredictable way. The tourists were contacted mainly in the hotels were they stayed. The hotels were surveyed during the weekends, but in several occasions no tourist was available. The excursionists were found walking or staying nearby restaurants or the waterfall. Although their selection was arbitrarily defined without concerning any kind of characteristic, the dependence on their acceptance to the interview and the reasonable chance of refusal made a truly random sampling impractical.

All the interviewees were asked about how much they were willing to pay monthly: (i) to recover and 


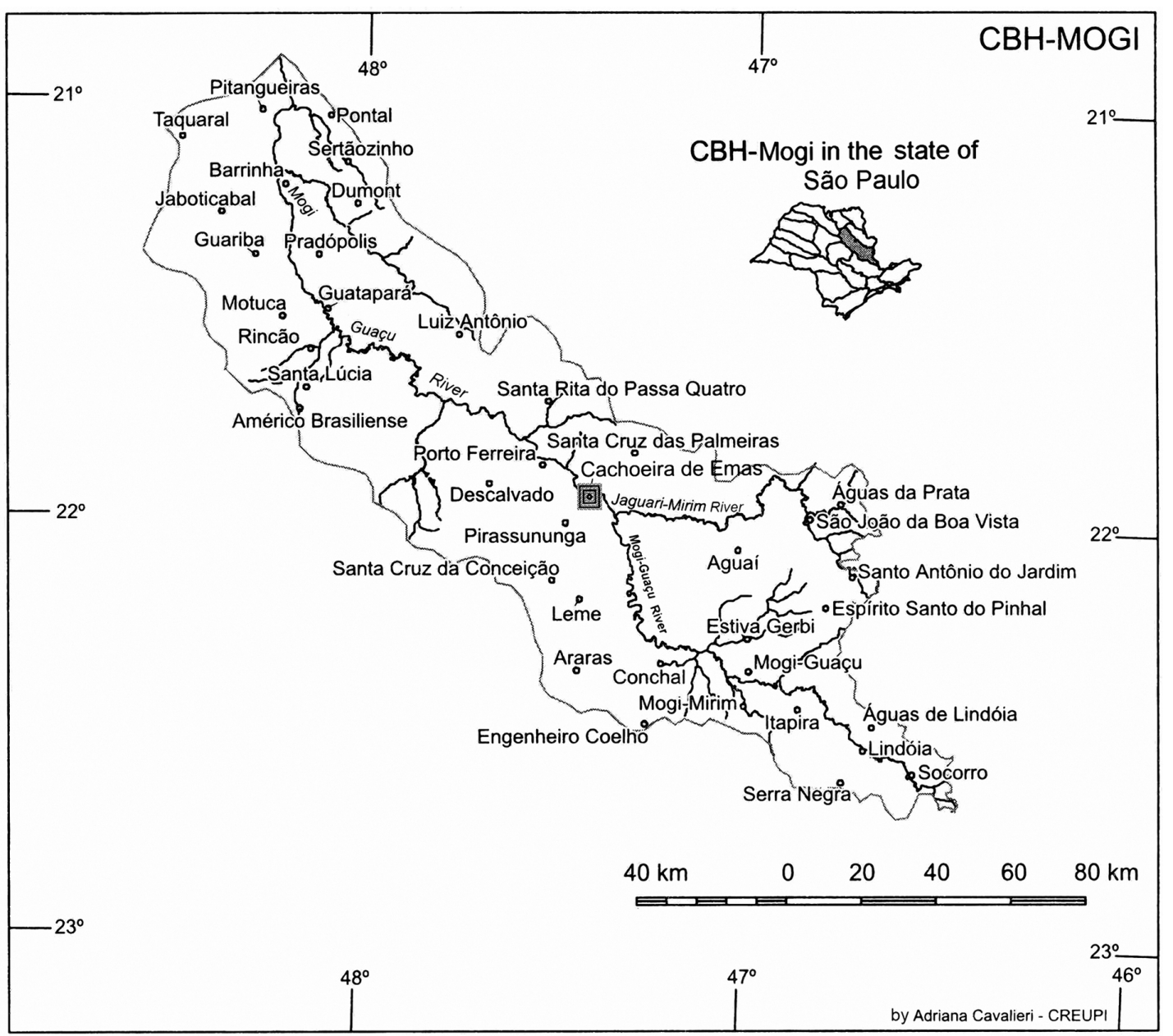

Fig. 1 - Location of Cachoeira de Emas in Mogi-Guaçu River basin inside the state of São Paulo. Adapted from CBH-Mogi and CREUP (1999).

(ii) to maintain the environment in current conditions. To aid choosing the values to be paid, it was read a text at the moment of each interview informing the general environmental conditions of the basin. It was taken information concerning socioeconomic conditions, as well as the site distance from the place where they live (sporting fisher, tourists and excursionists). According to Pâté and Loomis (1997), such information has an important role in determining the WTP for some public goods.

Each interviewee was asked to choose the certainty of payment in a scale from 0 to 10 , assuming this would come to be a reality instead of just a hypothesis. Using the same scale, they were also asked to evaluate the visited site, according to its importance to them.

Pollock et al. (1994) stated that the payment vehicle should be a bonus, a tax or a contribution, and it should be elaborated carefully in agreement with the perception of the target-public. In our case, the suggested vehicle of payment was an increment in the water bill. A payment card was presented with several values (from zero to US\$ 312.50 , including the option "other value") so that the interviewee could choose which value best corresponded to his/her maximum WTP.

\section{ANALYSIS}

We tested the influence of categorical and continuous socioeconomic variables of each public on WTP to maintain by means of a logistic regression, and on WTP to recover by an Analysis of Covariance (ANCOVA). These choices depended upon the balance between the zero and nonzero values in each response variable. The frequency of zeros of WTP to maintain was reasonably high, so it was not appropriate to deal with WTP as a 
continuous variable, and we categorize it to assume the value 0 (no willingness to pay) or 1 (willingness to pay, regardless of the amount). For this case, the logistic regression is an appropriate analysis (Hosmer and Lemeshow 1989, Kleinbaum 1996, Carvalho 2002, Quinn and Keough 2002). Concerning the WTP to recover, where almost all the interviewees would pay (many nonzero values), it was applied the ANCOVA (Quinn and Keough 2002). The response variable was transformed into the natural logarithm of WTP (R\$) +1 , to correct for problems of residual non-normality and heterocedasticity. The final analyses were done after removing outliers, both statistical (studentized residual >2) and conceptual outliers (WTP too inconsistent with family income). They included a sport fisher whose WTP to maintain and to recover were R\$500.00 (US\$ 312.50) and R \$ 1.000.00 (US\$ 625.00), respectively, while his declared family income was R $\$ 1.500 .00$ (937.50); and an excursionist with WTP to maintain and to recover equal to $\mathrm{R} \$ 50.00$ (US\$ 31.12) and $\mathrm{R} \$ 100.00$ (US\$ 62.50), but with a declared income of $\mathrm{R} \$ 500.00$ (US\$ 312.50). The last person also had a low certainty to pay ( 3 , in a scale from 0 to 10 ).

Table I presents the variables analyzed for each public. We selected just those more common in the literature and more linked to the family economics. All analyses were carried out in the statistical software Systat 10 . In order to not saturating the models, we tested only some interactions of interest concerning the two-way combinations of the variables: (i) education; (ii) family income; (iii) age and (iv) sex (in this case, for the tourists and excursionists). Only the main effects and significant interactions are presented in the Results' Tables.

\section{Protest ANSWERs}

Through the protest answers the interviewees could manifest their belief in the proper application of the economical resources they are hypothesized to pay for. In the Brazilian context this is an important issue as long as the corruption is well known to be present in all of the government levels by the general public, mainly through the television and newspaper media, which tend to stress this subject.

We also made analyses of logistic regression and ANCOVA after excluding the cases of protest answer.
At first, we considered as protest answers the cases in which the interviewees would not pay any value neither to maintain nor to recover the environment. Afterwards, we included as protest answers any of those which alleged corruption; those from people who argued that they already pay for the environment, but nothing is made in respect; those who do not give importance to the local study alleging they do not live near the Emas waterfall or in Pirassununga; those who believe that the government should pay, and those who alleged not having financial conditions. Such answers as "I do not know" were not included in analyses.

\section{Annual Aggregated Value}

The annual aggregated value (AAV) attributed to the Emas waterfall was calculated as a weighted sum, across all interviewed individuals, of their WTP (US\$/month) multiplied by 12 (months/year) and by the economically active population size (EAP) of the city from which each individual came. The result was then divided by the total number of interviewed individuals to correct for the multiple times the population sizes of cities entered the summation. For sport fishers, tourists and excursionists, the economically active portion of a city was considered here to be $1 / 3$ of its total population size (Pessoa and Ramos 1998 apud Carvalho 2002). The professional fishers were censed, so their total economically active population size was assumed as the number of interviewed people (33 individuals), who are not visitors, but live in the studied region. The annual aggregated value (AAV) was then calculated by the following equation:

$$
A A V=12\left(\sum_{i=1}^{N} W T P_{i} \cdot E A P_{i}\right) / N
$$

where $W T P_{i}$ is the $W T P$ of individual $i$ (to maintain or to recover); $N$ is the total number of interviewed people, and $E A P_{i}$ is the economically active population size of the city from which individual $i$ came. To exchange from Brazilian Real to US Dollar, we used the exchange rate 1US $\$=1.60 \mathrm{R} \$(04 / 07 / 2008)$.

We estimated the $95 \%$ confidence interval for AAV by means of bootstrap resampling, which tends to be fairly accurate at least for large sample sizes (Manly 2004). It consists in taking a large number of 
TABLE I

Variables tested in the logistic regressions and in ANCOVAs for the different publics of the Emas waterfall. Professional fishers (PF), sport fishers (SF), excursionists (EXC) and tourists (TOU).

\begin{tabular}{|c|c|c|}
\hline Variable & Public & Units \\
\hline \multicolumn{3}{|l|}{ Continuous } \\
\hline Children & PF, SF, EXC, TOU & Number of children \\
\hline Family income & PF, SF, EXC, TOU & $\mathrm{R} \$ /$ month \\
\hline Fishery income & $\mathrm{PF}$ & $\mathrm{Kg} /$ day \\
\hline Age & PF, SF, EXC, TOU & Years \\
\hline Travelling time & SF, EXC, TOU & Time to the waterfall (hours) \\
\hline \multicolumn{3}{|l|}{ Categorical } \\
\hline \multirow[t]{2}{*}{ Other activity } & $\mathrm{PF}$ & $\begin{array}{c}0 \text { - no (do not exert an economic } \\
\text { activity other than fishery) }\end{array}$ \\
\hline & & $1-$ yes \\
\hline \multirow[t]{2}{*}{ Civil state } & PF, SF, EXC, TOU & 0 - single \\
\hline & & 1 - married \\
\hline \multirow[t]{2}{*}{ Sex } & $\mathrm{EXC}, \mathrm{TOU}$ & 0 -male \\
\hline & & 1 - female \\
\hline Education* & PF & $\begin{array}{l}0 \text { - } \text { illiterate, } \\
\text { incomplete first degree, } \\
\text { coursing educational supplement; } \\
1 \text { - complete first degree, } \\
\text { incomplete second degree, } \\
\text { complete second degree }\end{array}$ \\
\hline \multirow[t]{4}{*}{ Education* } & $\mathrm{SF}$ & $\begin{array}{l}0 \text { - illiterate, } \\
\quad \text { incomplete first degree }\end{array}$ \\
\hline & & $\begin{array}{l}1 \text { - complete first degree, } \\
\text { incomplete second degree }\end{array}$ \\
\hline & & 2 - complete second degree \\
\hline & & 3 - graduate, post-graduate \\
\hline \multirow[t]{3}{*}{ Education* } & TOU, EXC & $\begin{array}{l}0 \text { - illiterate, } \\
\text { incomplete first degree, } \\
\text { complete first degree }\end{array}$ \\
\hline & & $\begin{array}{l}1 \text { - incomplete second degree, } \\
\text { complete second degree, } \\
\text { technical course }\end{array}$ \\
\hline & & $\begin{array}{l}2 \text { - incomplete undergraduate, } \\
\text { graduate, post-graduate }\end{array}$ \\
\hline
\end{tabular}

*The education categorization was specific for each public due to great differences among them. It was done in order to attain a reasonable balance of frequencies among each category.

random samples (100000 in our case) from the database, with replacement and of the same size, and recalculating AAV for each new sample. Then we had a resulting distribution with 100000 resampled values of AAV. As the resulting bootstrap distribution was markedly asymmetric, we opted to use the bias-corrected percentile method (Manly 2004) to calculate the $95 \%$ confidence limits. All the calculations above were made separately for WTP to maintain and to recover, generating different AAV estimations for each one. 


\section{RESULTS}

All categories would pay more to recover the environment than to maintain it (Table II). Coincidentally, the medians of WTP to recover and of certainty of payment are the same among categories. The fact that the mean values of WTP are higher than the median values is an indication that such variable has a rightskewed distribution. This is an expected result as the family income, which ultimately limits the WTP, tends also to have a right skewed distribution characterized by a general pattern of many poor and a few rich people. The opposite pattern was observed for payment certainty: a left-skewed distribution, which indicates that most people are reasonably sure to pay the value they proposed. More specifically, it is possible to check in Table II that more than a half people declared $100 \%$ certainty of payment.

From the 33 professional fishers, 16 (48.4 per cent) would not pay to maintain the environment in its current conditions, and 4 (12.1 per cent) would not pay to recover it, while 4 (12.1 per cent) would not pay neither to maintain nor to recover. Regarding the sport fishers, the numbers are 59 (55.14 per cent), 11 (10.3 per cent) and 11 (10.3 per cent), respectively. Regarding the tourists: 25 (55.5 per cent), 1 ( 2.2 per cent) 1 ( 2.2 per cent); and for the excursionists, 68 ( 66 per cent), 10 (9.7 per cent) and 9 ( 8.73 per cent).

The analyses of socioeconomic effects on WTP to maintain the environment show that age is the most important variable (Table III). Nonetheless, its effect was significant only for professional fisher and tourists: in both cases, a negative effect, which means that the older the people, the less probable they would pay to maintain the environment in its current conditions. Furthermore, the interaction between age and education was significant for excursionists. As the education category 2 was the reference category for this analysis, the negative coefficients of the two interaction components (with education 0 and 1) mean that for the less educated excursionists, the age effect tends to be more negative. After excluding the cases considered as protest answers, all the effects above were no longer significant.

Considering the WTP to recover the environment, the socioeconomic effects were more heterogeneous among the user categories than in WTP to maintain (Ta- ble IV). For the professional fisher, age and education effects were highly significant. As well as with WTP to maintain, the age effect was negative. The education in this case had also a negative effect. The adjusted mean (and standard deviation) for education level 0 was $3.283(0.669)$, which is larger than that for level 1 : 1.714 (0.687). Taking the original scale, the adjusted means are $\mathrm{e}^{3.283}-1=\mathrm{R} \$ 25.7$ or US $\$ 16.06$, and $\mathrm{e}^{1.714}-1=\mathrm{R} \$ 4.6$ or US\$2.87, respectively, which implies that less educated professional fishers (illiterate, incomplete first degree or coursing educational supplement) are supposed to pay five times more than more educated ones. Excluding the protest answers, only age kept a significant, and again negative, effect $(p=0.021)$. In this case, the protest answers were those in which the professional fishers would pay neither to maintain nor to recover the environment. The sport fishers' WTP to recover was significantly and positively influenced by the family income. This result does not change qualitatively after excluding the protest answers.

The tourists did not present any significant influence of socioeconomic variables on WTP to recover. On the other hand, the excursionists' WTP was significantly affected by sex and education. The adjusted means (and standard deviations) were $2.546(0.202)$ and 1.927 (0.170) for women and men, respectively. In original scales of WTP, the values are R $\$ 11.8$ or US\$ 7.37, and R $\$ 5.9$ or US\$ 3.68, respectively. This implies that excursionist women would pay twice more than men. The adjusted means, in original scale, for education levels 0,1 and 2 are: $\mathrm{R} \$ 4.9$ or US $\$=3.06$, R \$ 9.6 or US\$ 6.00 , and R\$ 12.1 or US\$ 7.56 , so the WTP tends to increase with education level.

Table $\mathrm{V}$ presents the annual aggregated value and its confidence limits. The value to recover the environment is 5 times larger than to maintain it in its current conditions. The confidence intervals are reasonably large and asymmetric (the upper limits are more distant from AAV estimations than the lower limits).

\section{DISCUSSION}

The professional fishers depend directly on the quality of the environmental resources they exploit for their subsistence. Therefore, it is expected that they are willing to pay more than the sport fishers, who use 
TABLE II

Monthly mean, standard deviation (SD), minimum, maximum, median, $25 \%$ and $75 \%$ quartiles $\left(Q_{1}\right.$ and $\left.Q_{2}\right)$, number of interviews $(N)$ of WTP to maintain and to recover the environment, and the payment certainty of the four user categories (R\$ $1.60=$ US\$1.00 04/07/2008).

\begin{tabular}{|c|c|c|c|}
\hline & $\begin{array}{l}\text { WTP to maintain } \\
\text { (US\$) }\end{array}$ & $\begin{array}{l}\text { WTP to recover } \\
\text { (US\$) }\end{array}$ & $\begin{array}{l}\text { Payment certainty } \\
\qquad(0-10)\end{array}$ \\
\hline Professional fishers & $\begin{array}{l}\text { Mean }=4.84 \\
S D=9.47 \\
\text { Min }(0 \%)=0 \\
Q_{1}(25 \%)=0 \\
\text { Median }(50 \%)=0.31 \\
Q_{2}(75 \%)=3.12 \\
\text { Max }(100 \%)=49.72 \\
N=33\end{array}$ & $\begin{array}{l}\text { Mean }=19.46 \\
\mathrm{SD}=34.72 \\
\text { Min }(0 \%)=0 \\
\mathrm{Q}_{1}(25 \%)=0 \\
\text { Median }=6.22 \\
\mathrm{Q}_{2}(75 \%)=9.38 \\
\operatorname{Max}(100 \%)=155.39 \\
\mathrm{~N}=33\end{array}$ & $\begin{array}{l}\text { Mean }=7.96 \\
S D=3.69 \\
\text { Min }(0 \%)=0 \\
Q_{1}(25 \%)=0 \\
\text { Median }=10 \\
Q_{2}(75 \%)=10 \\
\text { Max }(100 \%)=10 \\
\text { Did not know }=2 \\
\text { No information }=2 \\
N=29\end{array}$ \\
\hline Sport Fishers & $\begin{array}{l}\text { Mean }=6.91 \\
\mathrm{SD}=31.64 \\
\operatorname{Min}(0 \%)=0 \\
\mathrm{Q}_{1}(25 \%)=0 \\
\text { Median }(50 \%)=0 \\
\mathrm{Q}_{2}(75 \%)=3.12 \\
\text { Max }(100 \%)=310.77 \\
\text { Did not know }=4 \\
\mathrm{~N}=103\end{array}$ & $\begin{array}{l}\text { Mean }=17.37 \\
\mathrm{SD}=63.78 \\
\text { Min }(0 \%)=0 \\
\mathrm{Q}_{1}(25 \%)=2.19 \\
\text { Median }(50 \%)=6.22 \\
\mathrm{Q}_{2}(75 \%)=12.5 \\
\text { Max }(100 \%)=621.54 \\
\text { Did not know }=3 \\
\mathrm{~N}=104\end{array}$ & $\begin{array}{l}\text { Mean }=8.45 \\
\mathrm{SD}=2.33 \\
\operatorname{Min}(0 \%)=0 \\
\mathrm{Q}_{1}(25 \%)=8 \\
\text { Median }(50 \%)=10 \\
\mathrm{Q}_{2}(75 \%)=10 \\
\text { Max }(100 \%)=10 \\
\text { No information }=33 \\
\mathrm{~N}=74\end{array}$ \\
\hline Tourists & $\begin{array}{l}\text { Mean }=4.62 \\
\mathrm{SD}=11.62 \\
\operatorname{Min}(0 \%)=0 \\
\mathrm{Q}_{1}(25 \%)=0 \\
\text { Median }(50 \%)=0 \\
\mathrm{Q}_{2}(75 \%)=3.12 \\
\operatorname{Max}(100 \%)=62.15 \\
\mathrm{~N}=45\end{array}$ & $\begin{array}{l}\text { Mean }=16.10 \\
\mathrm{SD}=23.71 \\
\operatorname{Min}(0 \%)=0 \\
\mathrm{Q}_{1}(25 \%)=3.12 \\
\text { Median }(50 \%)=6.22 \\
\mathrm{Q}_{2}(75 \%)=25 \\
\operatorname{Max}(100 \%)=124.31 \\
\mathrm{~N}=45\end{array}$ & $\begin{array}{l}\text { Mean }=8.89 \\
\mathrm{SD}=2.24 \\
\operatorname{Min}(0 \%)=0 \\
\mathrm{Q}_{1}(25 \%)=10 \\
\text { Median }(50 \%)=10 \\
\mathrm{Q}_{2}(75 \%)=10 \\
\text { Max }(100 \%)=10 \\
\text { No information }=2 \\
\mathrm{~N}=43\end{array}$ \\
\hline Excursionists & $\begin{array}{l}\text { Mean }=1.53 \\
\mathrm{SD}=4.26 \\
\operatorname{Min}(0 \%)=0 \\
\mathrm{Q}_{1}(25 \%)=0 \\
\text { Median }(50 \%)=0 \\
\mathrm{Q}_{2}(75 \%)=0.62 \\
\text { Max }(100 \%)=31.08 \\
\text { Did not know }=02 \\
\text { No information }=01 \\
\mathrm{~N}=100\end{array}$ & $\begin{array}{l}\text { Mean }=8.42 \\
\mathrm{SD}=12.05 \\
\operatorname{Min}(0 \%)=0 \\
\mathrm{Q}_{1}(25 \%)=1.25 \\
\text { Median }(50 \%)=6.22 \\
\mathrm{Q}_{2}(75 \%)=12.5 \\
\text { Max }(100 \%)=62.15 \\
\text { Did not know }=02 \\
\text { No information }=01 \\
\mathrm{~N}=100\end{array}$ & $\begin{array}{l}\text { Mean }=8.01 \\
\mathrm{SD}=3.02 \\
\text { Min }(0 \%)=0 \\
\mathrm{Q}_{1}(25 \%)=7 \\
\text { Median }(50 \%)=10 \\
\mathrm{Q}_{2}(75 \%)=10 \\
\text { Max }(100 \%)=10 \\
\text { No information }=2 \\
\text { Did not know }=6 \\
\mathrm{~N}=82\end{array}$ \\
\hline
\end{tabular}

the environment just for leisure. Although on average the professional fishers of the Emas waterfall would pay more than the sport fishers to recover the environment, the median values were practically identical among these two categories, for both WTP to maintain and to recover. This indicates that for many sport fishers the environmental conditions of the Emas waterfall is also a matter of great concern. 


\section{TABLE III}

Results from the logistic regression analyses on the Willingness to Pay (WTP) to maintain the environment of the Emas waterfall in its current conditions. Considering the overall model for the professional fishers: Log-likelihood = $-18.573 ; X^{2}=8.571 ; d f=7 ; p=0.285 ; n=33$; sport fishers: Log-likelihood $=-64.802 ; \mathrm{X}^{2}=9.277 ; \mathrm{df}=8 ; \mathrm{p}=0.319 ; \mathrm{n}=102$; tourists: Log-likelihood $=-23.739 ; X^{2}=14.348 ; \mathrm{df}=8 ; p=0.073 ; n=45$; and excursionists: Loglikelihood $=-48.023 ; X^{2}=25.507 ; d f=10 ; p=0.004 ; n=97$.

\begin{tabular}{|c|c|c|c|c|}
\hline Response variable & Effect & Coefficient & SE & $\mathrm{p}$ \\
\hline \multirow{7}{*}{$\begin{array}{l}\text { WTP to maintain } \\
\text { (professional fishers) }\end{array}$} & Age & -0.090 & 0.042 & 0.031 \\
\hline & Civil state & -1.341 & 1.195 & 0.262 \\
\hline & Education & 1.447 & 1.272 & 0.255 \\
\hline & Other activity & -0.184 & 0.919 & 0.842 \\
\hline & Children & -0.117 & 0.344 & 0.735 \\
\hline & Family income & -0.000 & 0.001 & 0.485 \\
\hline & Fishery income & 0.053 & 0.049 & 0.273 \\
\hline \multirow{8}{*}{$\begin{array}{l}\text { WTP to maintain } \\
\text { (sport fishers) }\end{array}$} & Age & -0.037 & 0.021 & 0.077 \\
\hline & Civil state & 0.152 & 0.567 & 0.789 \\
\hline & Education 0 & 0.458 & 1.016 & 0.652 \\
\hline & Education 1 & -0.098 & 1.049 & 0.925 \\
\hline & Education 2 & -0.441 & 0.976 & 0.652 \\
\hline & Children & 0.092 & 0.158 & 0.562 \\
\hline & Family income & 0.0001 & 0.0002 & 0.058 \\
\hline & Travelling time & 0.075 & 0.331 & 0.821 \\
\hline \multirow{8}{*}{$\begin{array}{l}\text { WTP to maintain } \\
\text { (tourists) }\end{array}$} & Age & -0.132 & 0.059 & 0.024 \\
\hline & Sex & 1.135 & 0.769 & 0.140 \\
\hline & Civil state & -0.476 & 0.856 & 0.579 \\
\hline & Education 0 & -0.881 & 1.331 & 0.506 \\
\hline & Education 1 & -0.636 & 1.040 & 0.541 \\
\hline & Children & -0.338 & 0.405 & 0.404 \\
\hline & Family income & -0.000 & 0.000 & 0.600 \\
\hline & Travelling time & 0.864 & 0.549 & 0.116 \\
\hline \multirow{10}{*}{$\begin{array}{l}\text { WTP to maintain } \\
\text { (excursionists) }\end{array}$} & Age & 0.082 & 0.057 & 0.147 \\
\hline & Sex & -0.906 & 0.575 & 0.115 \\
\hline & Civil state & 0.496 & 0.570 & 0.384 \\
\hline & Education 0 & 5.333 & 2.833 & 0.060 \\
\hline & Education 1 & 4.981 & 2.929 & 0.089 \\
\hline & Children & -0.030 & 0.188 & 0.873 \\
\hline & Family income & 0.0001 & 0.0001 & 0.151 \\
\hline & Travelling time & 0.082 & 0.179 & 0.645 \\
\hline & Age* Education 0 & -0.158 & 0.063 & 0.012 \\
\hline & Age* Education 1 & -0.140 & 0.068 & 0.038 \\
\hline
\end{tabular}

Many fishers would pay to recover the environment, but not to maintain it in its current conditions, which could be due to their awareness about the MogiGuaçu River degradation along the stretch comprising the Emas waterfall. Both kinds of fisher are assiduous, and many of them have been fishing there since several years ago (Peixer 2008), which allowed them to accompany the ecosystem changing and the decreasing fish stock levels through time. The decision of not paying to maintain the environment emphasizes their dissatis- 
TABLE IV

Results from the Analyses of covariance (ANCOVAs) on the Willingness to Pay (WTP) to recover the environment of the Emas waterfall. Considering the overall model for the professional fishers: $R^{2}=0.542$; $n=32$; sport fishers: $R^{2}=0.080 ; n=103$; tourists: $R^{2}=0.248 ; n=$ 45; and excursionists: $R^{2}=0.175 ; n=97$. The response variable was transformed into $\ln (\mathrm{WTP}+1)$ before all ANCOVAs.

\begin{tabular}{|c|c|c|c|c|}
\hline Response variable & Effect & SS & $\mathrm{F}$ & $\mathrm{p}$ \\
\hline \multirow{7}{*}{$\begin{array}{c}\text { WTP to recover } \\
\text { (professional fishers) }\end{array}$} & $\operatorname{Age}^{1}$ & 19.304 & 17.995 & 0.0002 \\
\hline & Civil state & 1.026 & 0.957 & 0.338 \\
\hline & Education & 9.998 & 9.320 & 0.005 \\
\hline & Other activity & 1.862 & 1.736 & 0.200 \\
\hline & Children & 1.279 & 1.193 & 0.286 \\
\hline & Family income & 2.218 & 2.068 & 0.163 \\
\hline & Fishery income & 0.264 & 0.246 & 0.624 \\
\hline \multirow{6}{*}{$\begin{array}{l}\text { WTP to recover } \\
\text { (sport fishers) }\end{array}$} & Age & 0.680 & 0.416 & 0.521 \\
\hline & Civil state & 0.005 & 0.003 & 0.955 \\
\hline & Education & 2.451 & 0.500 & 0.683 \\
\hline & Children & 0.535 & 0.327 & 0.569 \\
\hline & Family income ${ }^{2}$ & 9.346 & 5.717 & 0.019 \\
\hline & Travelling time & 0.040 & 0.025 & 0.876 \\
\hline \multirow{7}{*}{$\begin{array}{l}\text { WTP to recover } \\
\text { (tourists) }\end{array}$} & Age & 1.356 & 1.003 & 0.323 \\
\hline & Sex & 5.105 & 3.776 & 0.060 \\
\hline & Civil state & 3.970 & 2.936 & 0.095 \\
\hline & Education & 6.241 & 2.308 & 0.114 \\
\hline & Children & 0.528 & 0.390 & 0.536 \\
\hline & Family income & 1.437 & 1.063 & 0.309 \\
\hline & Travelling time & 1.119 & 0.828 & 0.369 \\
\hline \multirow{7}{*}{$\begin{array}{l}\text { WTP to recover } \\
\text { (excursionists) }\end{array}$} & Age & 0.115 & 0.096 & 0.758 \\
\hline & Sex & 7.858 & 6.548 & 0.012 \\
\hline & Civil state & 0.266 & 0.221 & 0.639 \\
\hline & Education & 8.582 & 3.575 & 0.032 \\
\hline & Children & 3.026 & 2.521 & 0.116 \\
\hline & Family income & 3.950 & 3.291 & 0.073 \\
\hline & Travelling time & 1.780 & 1.483 & 0.227 \\
\hline
\end{tabular}

\footnotetext{
${ }^{1}$ Coefficient $=-0.070 ;{ }^{2}$ Coefficient $=0.0001$.
}

TABLE V

Annual aggregated values $\left(\mathrm{US}^{1}{ }^{1}\right.$ ) of WTP to maintain and to recover the Emas waterfall.

\begin{tabular}{c|c|c}
\hline Bootstrap estimates & Maintain & Recover \\
\hline Lower 95\% confidence limit & 2144210 & 22411965 \\
AAV & 11432128 & 55424283 \\
Upper 95\% confidence limit & 27861158 & 119230609 \\
\hline
\end{tabular}


faction with the ongoing situation.

The sport fishers would pay on average US\$ 82.92 annually to maintain, and US\$ 208.44 to recover the environment. The first value is comparable to the mean value declared by the sport fishers to prevent the extinction of native fish in the Murray River, Australia, which was \$A100 (= US\$ 95.16, using the exchange rate of $\$ A 1=$ US\$ 0.95 on 24/06/08) (Baker and Pierce 1997). It shows that sport fishers in these very different parts of the world have similar willingness to preserve the places that they use to leisure. Although the objective in the Australian case is more specific (avoiding extinction of native fishes), if we consider that fishes are the main subject for sporting fishers in our case as well, it can be concluded in a broad sense that both publics have almost the same interest in keeping the environmental conditions to support their activities. On the other hand, if we compare the willingness to maintain with willingness to recover, we see that, at least in our case, sporting fishers have a much larger interest (more than twice) in improving the environmental conditions than in just maintaining them.

The Emas waterfall has been visited by tourists, on average, since 12.7 years ago, and by excursionists since 10 years ago (Peixer 2008). The larger values declared by the tourists to maintain and to recover may be simply a reflex of their larger incomes: $\mathrm{R} \$ 2.778 .33$ on average, against R\$ 2.322.67 of excursionists (Peixer 2008). As well as the fishers, both the tourists and excursionists recognize that the river has some level of degradation, which is suggested by their higher WTP to recover when compared to the WTP to maintain the environment. Anyway, the Emas waterfall is an important leisure place for these people, as most of them would pay at least to recover it. The mean WTP to maintain and to recover for these two user categories, except the WTP to maintain of excursionists, were larger than the mean WTP of tourists visiting the Paraná River floodplain (US\$ 2.75). This is the value they would pay in order to restore and preserve the environment so that the touristic attractions would still exist (Carvalho 2007).

The same reasons affecting the WTP difference among tourists and excursionists in the present paper can explain their difference concerning the payment certainty, which was higher for tourists. It also applies to fishers: sport fishers have larger incomes, US\$ 1.212.37 against US\$ 575.52 of professionals, and have also higher payment certainties (Peixer 2008). The use of the payment certainty as a calibration scale follows what have been proposed in the literature (Champ et al. 1997 apud Samnaliev et al. 2003). These authors used a scale where only those WTP associated to certainty values higher than 8 should be interpreted as positive answers (Champ et al. 1997 apud Samnaliev et al. 2003). This is one more possible tool applied to reduce the hypothetical biases. In the present work, as the relative frequency of complete certainty of payment was very high, we opted to be not so conservative, and the payment certainty was used here mostly for illustrative purposes.

Two people, one sport fisher and one excursionist, were excluded from our analysis for declaring WTP values too high for their monthly incomes. Such data was interpreted as a warm glow bias. It happens when people feel moral satisfaction by choosing values to pay for an environmental good, independently of their current characteristics, and maybe they would not make it in the case of a real payment situation (Navrud 2001). This kind of hypothetical bias, if not identified properly, is one of the weaknesses of contingent valuation method. Breedlove (1999) analyzed other contingent valuation works and concluded that the method is still controversial due to its high complexity, its high costs and time demands, despite its wide application to subside decision making. Cantrell et al. (2004) took the same approach, suggesting that contingent valuation will remain controversial as it requires that the declared personal preferences be based on hypothetical situations, and there is no such a way to validate the results.

\section{SOCIOECONOMIC INFLUENCES}

The WTP to maintain was influenced mainly by age, at least for professional fishers and tourists. Older fishers tend to be more disappointed with the current environmental condition and fishing income. We hypothesized that they may be more pessimistic in relation to the environmental conditions where they live, as they know it since a longer time and have been observed the changes through which this environment has been passed. They are unsatisfied with the current landscape, and wish improvement, instead of just maintenance. Pauly (1995) 
points out that it is necessary to know the history of each fishery to better understand it, and to avoid the shifting baseline syndrome, when fisheries researchers use as reference the same early stock size and composition known at the beginning of their career. The professional fishers who have accompanied the environmental and fishery stock changing through time are important sources of information that should be considered in order to avoid wrong choices of reference points to ensure the maximum sustainable yield from fisheries. The older tourists tend also to be those who have been frequenting the waterfall since a longer time, and so are aware of the disturbances it has been suffering and more pessimistic with respect to the maintenance of its desirable features, despite still visiting the waterfall nowadays.

Excluding the protest answers from analysis removed all significant effects on the WTP to maintain the environment, which was the major effect of protest answers in our study and stresses their relevance concerning current environmental conditions. The same did not occur with WTP to recover, probably because this WTP had a more quantitative variation, but also because people may be more receptive to the idea of improving the environment. According to Dietz (2001), the psychologists and marketing professionals believe that people who do not answer to the questions have demographic and socioeconomic characteristics, attitudes and faiths that are different from those of people who use to answer them. This may be also the case in the present study. The fishers who choose not to pay due to some protest reason are probably from a different group, maybe those more pessimistic in relation to the future of their profession or even of a supposed recovery of the environmental quality. As the older people are the less probable to pay for environmental maintenance, according to our main criteria to define protest answers they are also the main group responsible for such answers in the interviews. This conclusion is also consistent with the fact that age was exactly the variable with no more significant effect after excluding protest answers from the analysis.

Considering the WTP to recover the environment, the socioeconomic variables that presented significant effects were age, education, family income and sex. Nevertheless, their effects depended strongly on which user category was analyzed, suggesting that the socio- economic features interact with user kind in influencing the WTP to recover. The reason why age affected negatively the WTP to recover of professional fishers is probably the same as that for WTP to maintain. However, considering the environmental recovering, the perspective is even more severe for these people: recovering generally takes substantial time to occur, so the older people will make less profit, if any, from its benefits. Besides, in most cases their children would not follow their profession, which probably makes them not judging important the environmental recovery for the future generations. Other difference between the age effects on maintenance and on recovering is that, instead of affecting a chance of a person be willing to pay, the effect on WTP to recover is quantitative: the older the people, the lower is the amount of money they would pay. It allowed the age to be significant even after the exclusion of protest answers from the analysis: the remaining cases were still sufficient to provide a correlation between age and WTP to recover. The education effect on the WTP to recover of professional fishers was the only with an unexpected direction: more educated fishers tend to pay less. This fact can be explained by the relationship between education and the dependence on the fishing activity: the smaller the education, the larger tends to be such dependence. More educated fishers have better perspectives of getting a job in other sectors. Anyway, the education effect was sensitive to protest answers, becoming non-significant after their removal. For excursionists, the education had an opposite, and expected, direction. Unlike the professional fishers, they are not so strongly linked to the place they are visiting, so the education level may contribute essentially with their awareness about environmental issues in general, and their importance to people's welfare. The WTP to recover of tourists was not influenced by any variable.

The excursionists' gender also affected their WTP to recover. Woman would pay more than man on average. She is probably more sensible in relation to environmental issues, and also more worried about the future conditions for the next generations of children and grandchildren, desiring the environment as a continuing option of accessible leisure for her family. In contrast, the study of Campbell (2007) found no influence of gender on WTP to improve the rural landscape 
in Ireland. White et al. (2001) studied the willingness to pay for the conservation of 4 species of mammals in North Yorkshire and, in this case, the gender was one of the variables that influenced WTP in the logistic regression. Nevertheless, the authors did not specify which gender would pay more.

Finally, the WTP to recover of sport fishers was only influenced by the family income. Such effect is quite reasonable, as the larger the income, the less limited is the person to choose any desirable value. Those who chose to pay seemed to be receptive to a possible project of environmental recovery and, in most cases, they understood its importance and realize that a fishing yield enhancement could result from it. This is corroborated by the results without protest answers, in which the highest values would be paid by those people with the largest incomes as they are the most probable to be able to assume one more economic tax, besides appreciating the local. Toivonen et al. (2004) studied the economical value of the recreational fishing in the Nordic countries (Denmark, Finland, Iceland, Norway and Sweden), and also found a positive relationship between WTP and family income.

The large number of statistical tests performed here could inflate the chance of committing the statistical type I error (Quinn and Keough 2002). In other words, multiple tests widen the possibility of getting significant results simply by chance, even if the null hypothesis is true. In our case, among the sixty tests presented in Tables III and IV, nine indicated a significant effect. If we assume these tests as independent, we can calculate the probability of getting at least nine significant results purely by chance among sixty tests, each with a significance level of 0.05 . Such probability, taken from a binomial distribution, is indeed very small: only 0.0028 or 0.28 per cent, which implies in a very little chance of committing a type I error by concluding in favor of significant results. So, we can be confident that the suggested socioeconomic effects are not a simple product of chance, but instead express systematic relationships. Also, almost all effects were in the expected directions, which consistently support our conclusions.

The annual aggregate value of the Emas waterfall shows how important it is considered by the visiting people and those who depend on it for professional fishing and survivorship. The annual aggregated value to maintain the environment was 5 times smaller than that for its recovering. It can be explained by the general awareness about the necessity to recover this environment. Although the huge difference between the estimates of AAV to maintain and to recover is uncontestable, their wide confidence intervals attest a still high level of uncertainty, even with a large sample size as in our study. The calculation of AAV given by Equation (1) can be very sensible to some sampling units, as each individual is associated to an entire city population. It may happen for instance if a rich person comes from a very large city (such as São Paulo), and suggest a high WTP value. Although a case like this is relatively rare (and this is taken into account by the calculation of Equation 1), it may suffice to produce a highly asymmetric distribution of AAV estimations (as indeed occurred with the bootstrap distribution, with many small and a few high values), inflating its confidence interval. Instead of indicating weakness of the specific formula here used to calculate AAV, this sensitivity may be better understood as an intrinsic property of the estimation of aggregated values by means of sampling individuals in locus. An ideal improvement would be interviewing people in every potential source city, but this procedure would require an enormous and impractical sampling effort. So, caution in interpreting absolute measures of aggregated values is advised, and any suitable procedure to estimate their degree of uncertainty is highly recommended.

Table VI makes a comparison between the estimated annual aggregated values of the Emas waterfall and other places. Even in its current condition (considering WTP to maintain), the Emas waterfall has a value greater than that of Jericoacoara beach, a well-known Brazilian touristic attraction (Martins 2002). Though, in this case, the author did not use the same methodology of the present work for calculating the annual aggregated value, so this comparison must be made with caution. The annual aggregated values here were significantly smaller than those found by Carvalho (2007), even when we consider the upper confidence limit of the AAV to recover (Table $\mathrm{V}$ ). It makes sense given the much larger scale and ecological relevance of the Paraná River floodplain, of which the Mogi-Guaçu River is just a tributary. On the other hand, the Emas waterfall has values comparable to the Platte River (Loomis et al. 
TABLE VI

Comparison of the annual aggregated value of the Emas waterfall with that of other places.

\begin{tabular}{|c|c|c|c|}
\hline & US\$ & Reference & Method \\
\hline \multicolumn{4}{|l|}{ Emas waterfal } \\
\hline Maintainance & 11432128 & This work & WTP \\
\hline Recovering & 55424283 & This work & WTP \\
\hline Jericoacoara beach (CE) & 1090000 & Martins (2002) & WTP (tourists) \\
\hline Jataí Ecological Station (SP) & 3212545 & Santos et al. (2001) & $\begin{array}{l}\text { Ecosystem services } \\
\text { and natural capital }\end{array}$ \\
\hline Paraná River floodplain & 122500000 & Carvalho (2007) & WTP (tourists) \\
\hline Platte River (Denver, CO) & $\begin{array}{l}19000000 \text { to } \\
70000000 \\
\text { (to recover) }\end{array}$ & Loomis. et al. (2000) & $\begin{array}{l}\text { WTP (families } \\
\text { living along } \\
\text { the river) }\end{array}$ \\
\hline
\end{tabular}

2000), whose range of estimations lies well inside our confidence intervals. Finally, the ecosystem services of Jataí Ecological Station, which is a preserved reserve located about 70 kilometers from the Emas waterfall, were evaluated in 3.2 million dollars by Santos et al. (2001). In this case they did not use the WTP, but their result allows forecasting the additional environmental goods and services provided by the Emas waterfall if it would be restored by any future project, as the two regions are very close geographically and share many biological and economical features.

The economic valuation is an additional tool to supply decision makers with reliable information about environmental importance and status, with the great advantage of using a common currency that everyone easily understands: money. Nevertheless, as any other information from the environmental research, it has always the risk of being only one more information if not really used for the decision making process in the public and politic domain. Besides, the WTP has a financial limitation determined by the total amount of financial resources available to countries or individuals and the priorities they establish (Fearnside 1997). Fortunately, it is expected nowadays an increasing willingness to pay for the environmental services as long as the effects of the global warming and climate change are becoming more evident for the general public and for the decision makers in special (Fearnside 1997).

The society needs adequate answers on what to preserve, where, how and why to preserve certain places or functions. The joined work of biologists, ecologists, and economists, among other professionals, can provide such answers, allowing for people to ex- press their demands and even to engage in environmental conservation and improvement. Despite the Emas waterfall not being a conservation unit, some measures as recovering the riparian vegetation, rational soil use, and the accomplishment of the legal reserves in the rural properties could promote the restoration of the potential environmental services in the overall area. As its direct users are well known and accessible people, the projects looking for its environmental recovery could find in this public a great support, even financial.

\section{ACKNOWLEDGMENTS}

We are grateful to the professional and sport fishers, tourists and excursionists who patiently answered the questionnaires. To CEPTA/ICMBio for the facilities and financial support. To UNESP for the facilities and institutional support. We thank also Prof. PhD. Adriana Rosa Carvalho for helpful suggestions throughout the development of this work, Izabel Boock de Garcia for helping formatting and submitting this manuscript, Prof. PhD. Carlos Edwar de Carvalho Freitas and an anonymous reviewer whose suggestions greatly improved the methodological and overall manuscript quality.

\section{RESUMO}

A Cachoeira de Emas, no Rio Mogi-Guaçu, é reconhecida regionalmente como um importante local para a pesca e o turismo. Os primeiros registros da pesca profissional e esportiva no local datam da década de 30 , que é o mesmo período em que a atividade do turismo teve seu início. O presente artigo fornece uma valoração ambiental deste local e identifica as diferenças entre os principais grupos de pessoas que o frequen- 
tam. Durante o ano de 2006 nós entrevistamos 33 pescadores profissionais, 107 pescadores esportivos, 45 turistas e 103 excursionistas para estimar a Disposição a Pagar (DAP) de cada categoria e para analisar a influência de fatores socioeconômicos através de regressões logísticas e ANCOVAs. A DAP dos pescadores profissionais foi significativamente influenciada pela idade e escolaridade e a DAP dos pescadores esportivos foi significativamente influenciada pela renda familiar. As variáveis que influenciaram a DAP dos turistas e excursionistas foram o sexo e a escolaridade. O valor anual total agregado para manter a Cachoeira nas condições atuais foi estimado em US\$ 81.080,00, e US\$ 44.055.911,46 para recuperá-la.

Palavras-chave: valoração contingente, pesca profissional, pesca esportiva, turismo, disposição a pagar.

\section{REFERENCES}

BAKER DL AND PIERCE BE. 1997. Does fisheries management reflect societal values? Contingent Valuation evidence for the River Murray. Fish Manag Ecol 4: 1-15.

BENI CB. 1998. Análise estrutural do turismo. Editora Senac, São Paulo, 427 p.

BREEDLOVE J. 1999. Natural Resources: assessing nonmarket values through contingent valuation. CRS Report for Congress. Available from URL:

http://www.ncseonline.org/NLE/CRSreports/Natural/nrgen-24.cfm (acessed in 05/01/2005).

BRIGANTE J ET AL. 2002. Avaliação ambiental do Rio MogiGuaçu: resultados de uma pesquisa com abordagem ecossistêmica. São Carlos: Rima Editora, 58 p.

CAmpbell D. 2007. Willingness to pay for rural landscape improvements: combining mixed logit and random-effects models. J Agric Econ 58(3): 467-483.

CANTRELL RN ET AL. 2004. Recreational anglers' willingness to pay for increased catch rates of Pacific threadfin (Polydactylus sexfilis) in Hawaii. Fish Res (68): 149-158.

CARVAlho AR. 2002. Valoração econômico-ecológica da planície de inundação do Alto Rio Paraná. PhD Thesis, Ecology of Aquatic Continental Environments, Maringá State University, Maringá, 112 p.

CARVAlho AR. 2007. An ecological economic approach to estimate the value of a fragmented wetland in Brazil (Mato Grosso do Sul State). Braz J Biol 67(4): 663-671.

CBH-Mogi AND CREUPI. 1999. Diagnóstico da Bacia Hidrográfica do Rio Mogi-Guaçu "Relatório Zero". Available from URL: http://www.sigrh.sp.gov.br/sigrh/ARQS/ RELATORIO/CRH/CBHMOGI/130/relmogiseg.pdf (accessed in 10/ 08/2006).
CHAMP P ET AL. 1997. Using donation mechanisms to value nonuse benefits from public goods. J Env Econ Manag 33(2): 151-163.

Costanza R. 1991. Assuring sustainability of ecological economic systems. In: CostanzA R (Ed), Ecological Economics: the science and management of sustainability. New York: Columbia University Press, p. 331-343.

DiETz BC. 2001. An analysis of statistical errors in contingent valuation surveys, Proceedings of the American Agricultural Economics Association Summer Meetings, 5-8 Aug 2001, Chicago, United States of America, 37 p. http://agecon.lib.umn.edu (accessed 25/05/2006).

FEARNSIDE PM. 1997. Environmental services as a strategy for sustainable development in rural Amazonia. Ecol Econ 20: 53-70.

GODOY MP. 1974. Contribuição à história natural e geral de Pirassununga. Manuscrito, v.1, Pirassununga.

Hosmer DW And Lemeshow S. 1989. Applied Logistic Regression. New York: Wiley-Interscience publication, $307 \mathrm{p}$.

Kleinbaum DG. 1996. Logistic Regression. A Self-learning Text. New York: Springer, $282 \mathrm{p}$.

LOOMIS J ET AL. 2000. Measuring the total economic value of restoring ecosystem services in an impaired river basin: results from a contingent valuation survey. Ecol Econ 33: $103-117$

MANLY BFJ. 2004. Randomization, bootstrap and Monte Carlo methods in Biology. Otago: University of Otago, $330 \mathrm{p}$.

MARTINS EC. 2002. O Turismo como alternativa de desenvolvimento sustentável: o caso de Jericoacoara no Ceará. $\mathrm{PhD}$ Thesis, Universidade de São Paulo - ESALq, Piracicaba, SP, $164 \mathrm{p}$.

Mattos KMC AND MATtos A. 2004. Valoração econômica do meio ambiente: uma abordagem teórica e prática. São Carlos: Rima Editora/FAPESP, 138 p.

Motta RS. 1998. Manual para valoração econômica de recursos ambientais. Ministério do Meio Ambiente, dos Recursos Hídricos e da Amazônia Legal. Brasília: IPEA/ MMA/PNUD/CNPq, 216 p.

NAVRUD S. 2001. Economic valuation of inland recreational fisheries: empirical studies and their policy use in Norway. Fish Manag Ecol 8: 369-382.

ORTIZ RA. 2003. Valoração Econômica Ambiental. In: MAY PH, Lustosa MC AND Vinha V (Org), Economia do Meio Ambiente: teoria e prática. Rio de Janeiro: Elsevier, p. 81-99.

PÂTÉ J AND LoOMIs J. 1997. Analysis - The effect of dis- 
tance on willingness to pay values: a case study of wetlands and salmon in California. Ecol Econ 20: 199-207.

PAUlY D. 1995. Anecdotes and the shifting baseline syndrome of fisheries. Trends Ecol Evol 10(10): 430.

PEIXER J. 2008. Características e valoração da pesca esportiva, profissional e do turismo da Cachoeira de Emas, no Rio Mogi-Guaçu/SP. PhD Thesis, Universidade do Estado de São Paulo (UNESP), Rio Claro, SP, 169 p.

PessoA R And RAmos FS. 1998. Avaliação de ativos ambientais: aplicação do método de avaliação contingente. Rev Bras Econ 52(3): 405-426.

Pollock KH, Jones CM And Brown TL. 1994. Angler survey methods and their applications in fisheries management. American Fisheries Society, Special Publication, n. 25 .

Quinn G And KeOUgh M. 2002. Experimental Design and Data Analysis for Biologists. Cambridge University Press, Cambridge, 537 p.
RIVAS A AND KAHN JR. 2006. Economia Ambiental e dos recursos pesqueiros. Manaus: Editora da Universidade Federal do Amazonas, 48 p.

Samnaliev M, Stevens T And More T. 2003. A comparison of cheap talk and alternative certainty calibrations techniques in contingent valuation. Working paper n. 2003-11. University of Massachusetts Amherst, Department of Resource Economics, 30 p. http://agecon.lib.umn.edu. (accessed in 25/05/2006).

SANTOS JE ET AL. 2001. The value of the ecological station of Jataí's ecosystem services and natural capital. Rev Bras Biol 61(2): 171-190.

TOIVONEn AL ET AL. 2004. The economic value of recreational fisheries in Nordic countries. Fish Manag Ecol 11: $1-14$.

White PCL, Bennett AC and Hayes EJV. 2001. The use of willingness-to-pay approaches in mammal conservation. Mammal Rev 31(2): 151-167. 